\title{
Bridging the Gap between Theory and Practice: Ecological Risk/Resilience Model Contributions to Special Education
}

\author{
Guadalupe Acle-Tomasini, Laura María Martínez-Basurto, Rosalinda Lozada-García \\ Faculty of Higher Studies Zaragoza, National Autonomous University of Mexico, Mexico City, Mexico \\ Email:gaclet@unam.mx,martinezblmaria@yahoo.com.mx,rosalindalozada@hotmail.com
}

Received 31 March 2016; accepted 28 May 2016; published 31 May 2016

Copyright $@ 2016$ by authors and Scientific Research Publishing Inc.

This work is licensed under the Creative Commons Attribution International License (CC BY). http://creativecommons.org/licenses/by/4.0/

(c) $\underset{\mathrm{EY}}{\mathrm{Er}}$ Open Access

\begin{abstract}
The purpose of educational resilience is to understand why some students from adverse environmental backgrounds and communities succeed while others from equally adverse conditions do not. Resilience must not be regarded as an exclusive attribute of students but as the intertwined relationship between children's abilities and the abilities of individuals within their family, school and social contexts. This proposal of an ecological risk/resilience model in special education is derived from the resilience perspective and is based on Bronfenbrenner's (1994) ecological model of development, and contributions in the study of resilience (Rutter, 1993). This proposed model lays the foundation for specific assessment/intervention program development focused on altering the way special education students interact with different people and within different contexts, in order to promote resilient behaviors in the actors involved in their academic achievement and adaptation, and educational inclusion. A special emphasis is made on early intervention, when children start schooling and may face academic risks due to their special educational needs. The basis for this model, the dynamics of implementation and the main results are described.
\end{abstract}

\section{Keywords}

Ecological Risk/Resilience Model, Special Education, Students at Risk, Early Intervention, Social Validity

\section{Introduction}

The importance of special education field is noticeable worldwide, and individual with special educational needs

How to cite this paper: Acle-Tomasini, G., Martínez-Basurto, L. M., \& Lozada-García, R. (2016). Bridging the Gap between Theory and Practice: Ecological Risk/Resilience Model Contributions to Special Education. Creative Education, 7, $1093-1110$. http://dx.doi.org/10.4236/ce.2016.77114 
belong to every social class. An important change in special education has been the notion that, for diagnosis, control and suppression, disability should not only be defined based on the description of personal characteristics, but also on the interaction between individuals' characteristics and particular challenges in every environment that shape them. Consequently, a way to address educational work is to study gifted individuals or individuals with special educational needs in view of this complex interaction with the environmental forces surrounding them (Acle-Tomasini, 2006). Special education will be always related to political, social, and cultural contexts, and the definition of normalcy will depend on the reference points of social, peer, and family groups, as well as the specific circumstances (Gargiulo, 2012).

Due to the commitments assumed by many countries before the UNESCO since 1994, the Inclusive Education plan has prompted a series of changes both in special education policies and management, and services. This has had consequences such as the disagreement over definitions of disability and special educational needs, the lack of appropriate resources, and limited scientific data on effective interventions, as well as negative attitudes towards those who are different, to name a few (Sánchez, Acle, de Agüero, Jacobo, \& Morales, 2003; Zipper \& Simeonsson, 2004). So special education students whose educational needs have not been successfully met for them to achieve fully school, educational, and social inclusion may find themselves in a situation of vulnerability and educational risk. This, together with the adverse factors within their family or social context, may further compromise their development.

In this sense, the study of resilience in the education field has its purpose to understand why some students from adverse environmental backgrounds and communities succeed while others from equally adverse conditions do not. In education, a resiliency-based perspective is used by focusing more on the predictors of academic success rather than on those of academic failure, and it also allows for the design of effective educational interventions that do in fact provide protective mechanisms to reduce risk factors. Educational resilience must not be viewed as an exclusive attribute of students, but as the intertwined relationship between children's abilities and the abilities of individuals within their family, school, and social contexts (Waxman, Padrón, \& Gray, 2004). Education professionals have adopted resilience as a strength- or solution-based approach, the purpose of which is always to improve educational outcomes for students.

The definitions of risk and relevant factors have been given: Brown (2004) explained that in 1983 a report called "A Nation at Risk: The Imperative for Educational Reform", issued by the National Commission on Excellence in Education, identified the factors that exposed American children to academic risk. Following the publication of this report, scientific research on those factors nationwide began, because it was important to determine significant risk factors to promote protective ones and tackle failure. In 1992, the California Department of Education published a list of 36 risk factors associated to school failure, which were divided into the following categories: 1) individual; 2) family; 3) school; 4) community; and 5) high risk.

However useful this specific risk-oriented model was back then-many national programs were developed and implemented to prevent these risks from causing an impact — as noted by Brown (2004), it was not until the resilience constructs and its correlated factors were established that a generalist orientation model based on Bronfenbrenner's (1994) ecological model of human development was proposed. This emphasized how resilience will always be linked to the child's global environment. Thus, knowing the relation between the different systems will help to detect strengths and interests for building resilience. In the ecological perspective, school is a habitat created by man, of all-importance to him, since it is there where he spends most of his educational years. It is an organic, dynamic environment, determined by a variety of perceptions and interactions between individuals. Thus, studying school as an interactional system (i.e. a group of individuals and their relationships with each other and their attributes) means a transition from a linear epistemology to a circular epistemology. Viewing school as a system entails to look at it through its members, the interactions established among them, and the regularity observed in their behavior sequences repeated over time that originate behavior rules or standards (Eggleston, 1977).

In this regard, Kauffman (1995) states that ecological principles have significant implications for special education. In his opinion, special education teachers analyze how an individual's or group's quality of life is altered by someone occupying certain niche and altering the ecosystem. There is clear evidence that responses to different environments vary widely. Individuals are also markedly different based on how they perceive a given environment, and so are the means by which they feel effectively encouraged to learn specific abilities and find friendship networks that maintain pro-social behavior. Consequently, Kauffman highlights the need to build an all-inclusive general social system that comprises a variety of environments directed towards the diversity of 
population backgrounds.

Otherwise, academic failure has consequences not only for individuals but also for society; therefore, the toll it takes becomes significant. Future implications for children who do not acquire minimum abilities fostered during primary education may be of importance when as youngsters they have to use these to function properly in society. Moreover, as noted by Richman, Bowen, \& Woolley (2004), school failure may seem to affect, for the most part, populations in economically- and socially-disadvantaged and exclusion conditions, as identified by UNESCO (2003). These conceptions are a distal variable that has had a direct effect on programs or behaviors followed at schools regarding special education students.

The educational programs that seek to provide normal experiences to special education children are a reference of the complexity of transactions of children with different environments (Desatnik, 2009). The way a child with difficulties benefits or not from the inclusive education program will depend on multiple mediators, not only personal but also school, family, and social. A child may acquire abilities to face disadvantage and develop in a healthy way or not. Zipper and Simeonsson (2004) state that a protective factor per se cannot foster development in a special education child if the required transactional task is not carried out: each person involved can help to foster the appropriate development of the child. Analyzing risk and protective factors, along with mechanisms and mediators, will serve as the basis for the development of evidence-based special education prevention and intervention programs (Cook, Tankersley, Cook, \& Landrum, 2008).

According to Murray (2003) and Wiener (2003), a risk-resilience model provides the basis for exploring the impact that individual, school, social, and contextual experiences have on long-term achievements of children with different special educational needs. Thus, understanding how risk and protective factors operate during special education children's lifetime will provide both researchers and practitioners with necessary scientific evidence to implement appropriate intervention and prevention programs. According to Margalit (2003), resilience research is expected to identify complex transactions, and both internal and external risk factors involved in that process, a claim that lays the foundation for the ecological perspective.

Donahue and Pearl (2003) revisit the ecological approach by noting that studying social dimensions of students with learning disabilities sheds light on the multiple and interactive characteristics of these students with their social and cultural environments. These authors emphasize the following aspects of risk/resilience: 1) it recognizes that studying one single factor is insufficient to advance theory; 2) individual differences must be taken into account by any viable theory to explain these issues; 3 ) the special education field maintains that children facing multiple adverse situations may achieve positive outcomes; 4) assuming that protective factors emerge from a wide network (e.g., within the individual, the family, the school, the community, the culture) should guide resilience researchers; 5) focusing on developmental and longitudinal perspectives promotes optimism for working with children from poor environments whose early prognosis is unfavorable. In fact, risk/resilience models can help to explain what may be beyond and how some adverse factors may eventually play a protective role and vice versa; 6) no particular theory of child development is privileged because it is important that a variety of perspectives be taken into account to hypothesize about risk and protective factors, as well as their interaction, to promote resilient behaviors; 7) regarding learning disabilities, some aspects are proposed to be taken into account: type of problems, diversity, age of identification, and chronicity. Donahue and Pearl postulate that risk and resilience factors are partially dependent on gender, cultural values, and ecological contexts.

The aforementioned underlines the importance of analyzing risk factor differential effects on development in special education children. The complexity of an ecological approach requires studying how risk and protective factors are associated or whether they help children and families in adverse circumstances develop resilient behaviors or not. As established by Zipper and Simeonsson (2004), there is a conviction that studying the complex interaction among these factors and their impact on child and family development will lead to the development of programs aimed at reducing risk and increasing protection, which can be achieved by enrichment programs within different child development environments. By acknowledging this, future policies, family support promotion, inclusion services improvement, and better services for communities may be attained. Lastly, the essential relationship between research and practice is stressed as a means to achieve the aforementioned.

In this sense, by studying the way a special education child's interactions occur with different individuals from his family and school contexts, more accurate indicators could be provided and used to decide in which to intervene more accurately (Acle-Tomasini, 2012). Fraser (2004) suggests that this way of addressing a risk/resilience situation be called multi-systems perspective, because every environment mentioned above has a specific influence level on child development. Family may be considered both a higher and lower level within 
the child's ecology, and school and community as well. In order to elucidate this, Fraser (2004) and Benard (2004) also mention that when identifying risk or protective factors that affect or influence development, three main interrelated systems must be addressed: 1) biological and psychological characteristics; 2) family factors; and 3) environmental conditions, including school and communities in which children develop.

From the ecological perspective, individuals, families, schools, communities, or societies may be found to be at risk, as established above. So which system should we effectively focus on in order to achieve a positive adaptation of at-risk students? Which system has the largest number of protective factors to reduce risk? To answer these questions, some authors such as Fraser and Galinsky (2004) noted that in this perspective the causal order is not always easy to find. What remains clear is that the relationships individuals establish with their environment are reciprocal, and it is the accumulation of risk in those interactions what can be viably characterized, rather than a particular risk sequence. Accordingly, a special education and disabled child's needs may not be met successfully, given poverty conditions or school lacking qualified personnel or needs not been appropriately identified or family not being able to attend these needs. There are many accumulated risk chains that compromises the development of a child with this type of educational needs.

Evidence-based special education practices are fundamentally collaborative in the sense that the child and his or her school and family micro-systems are involved in defining the problem, selecting and applying strategies to solve it, and assessing outcomes. Basic strategies will be aimed at reducing risks and promoting protection. This includes, as suggested by Benard (2004), Fraser and Galinsky (2004), and Stormont (2007), the assessment of individual, school, family, and social risk factors; the recognition that the student is in a vulnerable situation in his or her dynamic interrelation within said contexts; and the identification of individual, school, family, and social protective factors, so as to put the focus of intervention programs on strengthening the latter in order to reduce the effects of the accumulated risk chains previously assessed.

Based on the aforementioned, an ecological risk/resilience model in special education is proposed. This model promotes specific assessment/intervention planning aimed at altering special education students' interactions with different individuals and within different contexts in which they develop, so as to promote resilient behaviors in the different actors involved in their learning achievements and school adaptation. Early intervention is particularly emphasized when children start schooling, and due to their special educational needs may find themselves in educational risk situations. The general framework followed to implement ${ }^{1}$ programs based on the ecological risk/resilience model in special education aimed at integrating theory, practice and research is illustrated in Figure 1.

\section{Method}

\subsection{General Objectives}

1) To establish and socially validate an ecological risk/resilience model that promotes resilient behaviors in

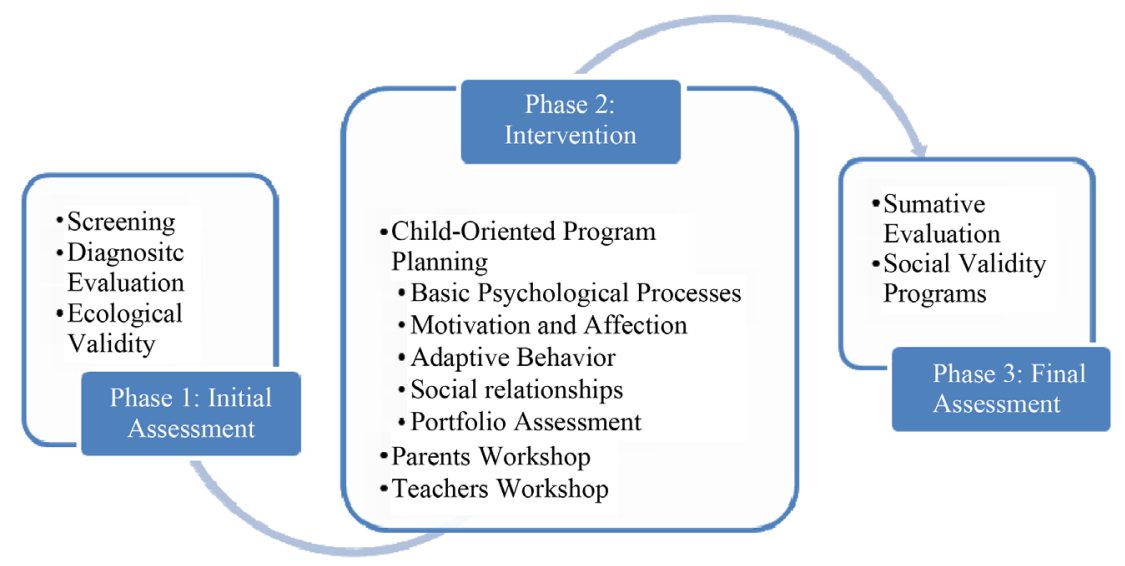

Figure 1. Proposed Intervention assessment programs based on the ecological risk/resilience model in special education (Acle-Tomasini, 2012).

${ }^{1}$ These programs have been implemented by students of the Special Education Residency program, which is part of the Master of Psychology program at the Faculty of Higher Studies Zaragoza, throughout the two-year duration of this training program. 
special education students, fathers, and teachers.

2) To reduce risk factors and strengthen protective factors in special education student's interactions with school and family contexts.

3) To promote educational adaptation and inclusion of special education students from regular schools.

\subsection{Context and Settings}

Iztapalapa is one of Mexico City's municipalities and has the largest percentage of population (INEGI, 2010). It is an area of irregular settlements, migrant population and a dramatic demographic growth. According to the Secretariat of Public Education (SEP, 2000), it is a municipality characterized by high crime and public insecurity rates, accelerated population growth in irregular settlements, high mobility of faculty and executive personnel at schools and group overcrowding. Moreover, SEP states that basic education students from this municipality sometimes present with - although there is no information about how this was determined-emotional disorders such as violent behavior, isolation, attention deficit, poor development of higher mental functions and drug addiction and gang involvement risk, which highlights the vulnerability context in which children live. All 4 public schools where different programs under the proposed approach were implemented are located within the context mentioned above. Three of them work school hours from 8:00 a.m. to 12:30 p.m., and the other one is considered full-time, with school hours from 8:00 a.m. to 16:00 p.m.

\section{General Procedure}

Since 2006, principals and teachers of 4 schools located in Iztapalapa municipality were introduced to the project. Then, the main focus agreed upon was to identify children with special education needs when they start schooling. It is worth underlining that faculty members expressed that by giving importance to centering detection on the first grades, at-risk students' learning would be influenced more in the following grades, and educational lag or dropout would be prevented. Since 2006, the implementation of programs based on the ecological risk/resilience model is planned as follows (Figure 1):

1) Informed consent is required both from authorities and teachers, allowing for scheduling activity sessions with the children;

2) First and second grade students' parents are briefed on the project, and are required to give informed consent for their children to participate, and for themselves to participate later in an interview and scheduled workshops;

3) Consent to work with the team is provided by children. As part of the exploratory evaluation, the WISC-IV test is first administered to every first- and second-grader. Upon a result analysis, principal and relevant grade teachers are expected to agree upon the students eligible for diagnostic evaluation;

4) Students eligible for diagnostic evaluation complete both formal and non-formal tests based on the special education category into which they have been hypothesized to fall. Simultaneously, parents and teachers provide relevant information to profile risk/resilience and make a final decision as to which students require intervention;

5) Intervention programs are developed and implemented based on the children's characteristics and specific needs. During program administration, an unabridged evaluation is conducted to serve as feedback for activities. Parent workshops are built and their orientation is determined by which category children fall into and their own needs as parents. Likewise, teacher workshops are designed and offered. Portfolio assessment is used;

6) During the final assessment, post-test of initial assessment tests administered to children was first carried out, and then the Social Validity questionnaire was administered to parents and teachers;

7) Result analysis: Data was both quantitatively and qualitatively analyzed. Descriptive, non-parametric statistics were used and helped to contrast students' performance before and after the program, among other features. The activities that have been conducted over the last 10 years in every phase are described below with the purpose of showing the followed dynamics and main results.

\subsection{Initial Assessment: Screening}

Its main purpose is to establish a risk/resilience profile at individual, school, family and social levels of students in the first two primary education grades in order to identify those at educational risk. 


\subsubsection{Participants}

Table 1 shows that the number of children subjected to the evaluation from the 2006-2007 to the 2014-2015 school years was $1022.51 .86 \%$ of them were in first grade, $47.06 \%$ in second and $1 \%$ in third. Participants were $50.49 \%$ male and $49.51 \%$ female, with an average age of 6.8 years for students in first grade, 7 years for students in second grade, and 8 years for students in the third grade.

\subsubsection{Instruments}

- Wechsler Intelligence Scale for Children-Revised (WISC-R) (Wechsler, 1981). It has two subscales, Verbal and Performance, into which are organized 6 subtests that measure different basic psychological processes. For the WISC-R version in Spanish, reliability coefficients for every independent subscale were sufficient. The average coefficient range was from .77 to .86 for verbal subscales and from .70 to .85 for performance subscales. This scale was used at the beginning of the project.

- Wechsler Intelligence Scale for Children-Fourth Edition (WISC-IV) (Wechsler, 2007). The WISC-IV, the purpose of which is to measure the intelligence quotient of children and adolescents between the ages of 6 and 16, obtained a total reliability level between .91 and .93 . The four indexes that measure performance (i.e. the Verbal Comprehension Index, the Perceptual Reasoning Index, the Working Memory Index, and Processing Speed Index) obtained reliability ranges from .88 to .97 . For having been validated in Mexico, it is considered to be a reliable instrument (Esquivel, Heredia, \& Lucio, 2007). It has been used since its publication and validation for the Mexican population.

- An observational log book for monitoring the child's behavior during the administration of the instrument.

\subsubsection{Results}

An average of $54.5 \%(n=531)$ of children evaluated were identified to have possible special educational needs. This indicates that through this period a high incidence of educational risk among children who start schooling is found. This result is significant when considering UNESCO's (2003) predictions about only $10 \%$ of a given population being expected to present special education needs. 531 children were eligible for the following phase as described below.

\subsection{Diagnostic Evaluation}

\subsubsection{Instruments}

A list of instruments, whether formal or non-formal, that were important to analyze intra- and inter-individual

Table 1. Number of participants that completed the exploratory evaluation by gender, grade and school year.

\begin{tabular}{|c|c|c|c|c|c|c|c|c|c|c|c|c|c|c|}
\hline \multirow[t]{2}{*}{ School Year } & \multirow[t]{2}{*}{ School } & \multicolumn{4}{|c|}{$\mathrm{n}$ /grade } & \multicolumn{4}{|c|}{ male/grade } & \multicolumn{4}{|c|}{ female/grade } & \multirow[t]{2}{*}{$\begin{array}{l}\% \text { at } \\
\text { Risk }\end{array}$} \\
\hline & & $\mathrm{T}$ & $1^{\circ}$ & $2^{\circ}$ & $3^{\circ}$ & $\mathrm{T}$ & $1^{\circ}$ & $2^{\circ}$ & $3^{\circ}$ & $\mathrm{T}$ & $1^{\circ}$ & $2^{\circ}$ & $3^{\circ}$ & \\
\hline 2006-07 & S1 & 206 & 100 & 106 & & 92 & 42 & 50 & & 114 & 58 & 56 & & 36 \\
\hline 2008-09 & S1 & 102 & 76 & 26 & & 57 & 40 & 17 & & 45 & 36 & 9 & & 57 \\
\hline \multirow{3}{*}{ 2010-11 } & S2 & 156 & 75 & 70 & 11 & 85 & 37 & 41 & 7 & 71 & 38 & 29 & 4 & 50 \\
\hline & S3 & 81 & 43 & 38 & & 47 & 26 & 21 & & 34 & 17 & 17 & & 53 \\
\hline & S4 & 78 & 39 & 39 & & 39 & 19 & 20 & & 39 & 21 & 18 & & 55 \\
\hline \multirow{3}{*}{$2012-13$} & S2 & 96 & 62 & 34 & & 45 & 30 & 15 & & 51 & 32 & 19 & & 49 \\
\hline & S3 & 114 & 38 & 76 & & 53 & 17 & 36 & & 61 & 21 & 40 & & 53 \\
\hline & S4 & 61 & 29 & 32 & & 36 & 21 & 15 & & 25 & 10 & 15 & & 80 \\
\hline \multirow{2}{*}{ 2014-15 } & S3 & 55 & 31 & 24 & & 30 & 17 & 13 & & 25 & 14 & 11 & & 56 \\
\hline & S4 & 73 & 37 & 36 & & 32 & 16 & 16 & & 41 & 21 & 20 & & 56 \\
\hline TOTAL & & 1022 & 530 & 481 & 11 & 516 & 265 & 244 & 7 & 506 & 268 & 234 & 4 & $\mathrm{M}_{\text {risk }}=54.5$ \\
\hline
\end{tabular}

Note: The public schools keep the order in which we began the intervention programs. 
differences of children with special education needs as well as to characterize an individual, school, family, and social risk/resilience profile is outlined.

- Literacy Assessment (Evaluación de la Lectura y Escritura, [ELE] Martínez, 2008). A non-formal test to know writing, reading comprehension, oral expression and organization of ideas in speaking and writing skills.

- Mathematical Skills Assessment for First Grade Children (Prueba de Habilidades Matemáticas para Niños de Primer Ciclo, [PHM] Álvarez \& Romero, 2012). Non-formal test with the purpose of characterizing mathematics skills of children in first grade.

- Written and Spoken Language, Socialization and School Perception Form (Formato de percepción sobre lenguaje oral y escrito, socialización y escuela, Martínez, Lozada, \& Acle, 2013). A non-formal test that inquiries into children's learning skills, strengths, weaknesses, academic abilities, like and dislikes. The parent or legal tutor is tested individually so that he or she can answer in detail.

- Test of Creative Thinking, Figural Form 1A (Torrance, 2008). A formal test of the use of imagination to evoke original responses by completing a series of drawings. The level of creativity is scored by grade or age based on indicators of creativity used in the test. The average reliability score of this instrument ranges from .89 to .94 . It is appropriate for individuals from preschool through undergraduate school and is administered individually or in groups.

- Student Motivation Scale for Children (Escala de Motivación Escolar en Niños, Romero, 2008). A Likerttype scale with 30 items organized into six dimensions (i.e., academic interest, academic persistence, academic effort, recreational interest, recreational persistence, and recreational effort) with a 4-option scale: 1) never; 2) rarely; 3) often; and 4) always. Reliability score was .86.

- House-Tree-Animal (Buck \& Warren, 1994). A projective or graphical test intended to learn how children think and feel about themselves and the most important individuals in their lives. It helps to know the most relevant aspects about personality, such as desires, fears, likes and dislikes.

- Guide for Interviewing Parents (Acle \& Roque, 2006). A guide with the purpose of learning important information about students and various household characteristics that influence their learning, dimensions that allow us to identify risk and protective factors at family, social and school levels.

- List for the Identification of Gifted Potential in Primary Education Children (Lista para identificar el potencial sobresaliente en niños que cursan la educación primaria, Covarrubias, 2001). A non-formal test with two versions, one for parents and one for teachers. The purpose of this test is to measure the perception of gifted potential by parents and teachers. It comprises 25 statements that describe some gifted students' characteristics and two response options indicating either the presence or the absence of a characteristic.

- Behavior and Attitude Checklist (Sattler, 2003). A non-formal instrument aimed at monitoring the child's behavior and attitude during assessment. It is the psychologist who completes this once the assessment is finished. It includes 13 areas related to observed attitude, habits and skills in students.

- Sociogram (Moreno, 1954). A tool that allows us to distinguish the inter-relational basic structure of a group through their members' responses about their own attractions and rejections. It is administered in group. Students nominate three peers with whom they play, with whom they do not play, with whom they study, with whom they do not study, as well as three peers who get in trouble and three who behave appropriately.

- Adaptive Behavior Inventory for Parents (Inventario de conducta adaptativa versión para padres) (Meléndez, 2007). A non-formal instrument intended to learn which tasks children complete on a daily basis in the following 9 of 10 applicable adaptive behavior areas: Functional Academics, Communication, Self-Care, Independent Living, Social Skills, Community Use, Self-Direction, Health and Safety, and Leisure. It consists of 52 statements with a five-option response Likert-type scale: 1-never, 2-rarely, 3-frequently, 4-always, and 5 -not required, to measure how children function within an environment such as their home or community by analyzing the frequency with which respective tasks are completed.

- Inventario de conducta adaptativa versión para profesores (Adaptive Behavior Inventory for Teachers) (Meléndez, 2007). It helps to learn which tasks children complete on a daily basis in the following 9 of 10 applicable adaptive behavior areas: Functional Academics, Communication, Self-Care, Independent Living, Social Skills, Community Use, Self-Direction, Health and Safety, and Leisure. It consists of 44 statements with a five-option response Likert-type scale: 1-never, 2-rarely, 3-frequently, 4-always, and 5-not required, to measure how a child functions within an environment such as home or community by analyzing the frequency with which respective tasks are completed.

- Activity Log. It consists of recording activities and observations in the primary school regarding context, fa- 
cilities, participants, relationships, and events during practice, as well as experiences from every session ${ }^{2}$.

\subsubsection{Results}

As Table 2 shows, of the total of children evaluated $(n=531), 2.45 \%$ fell into the Intellectual Disability (ID) category, 22.26\% into Low Intellectual Performance (LIP), 19.77\% into Behavior Problems (BP), $22.97 \%$ Written and Spoken Language Disorder Disorders (W/SLD) and Learning Disabilities (LD), 9.22\% into Language Impairment (LI), and $23.35 \%$ into Giftedness (G). Every category shows a high percentage, which may very well be indicative of an individual risk that, if left unattended at this early stage, could become a major educational risk factor. Moreover, it is important to highlight that these special education categories persisted among the different groups of 1st and 2nd grades, regardless of school year and even if percentage by category may vary from year to year. It is important to detect ID and LIP in children for three reasons: 1) children between 6 and 8 years old are developing; 2) adversity conditions in which they live may influence outcomes; and 3) the odds of fostering their intellectual potential may contribute to improve school learning.

In addition to the risk factor mentioned above, the risk/resilience profile was characterized at the individual, family, school and social levels, as illustrated by the different elements in Table 3. It is important to highlight that the risk/resilience model approach in special education essentially acknowledges that both types of factors coexist. Thus, it is important to analyze which of them exerts more influence on problem occurrence in order to guide action, namely to reduce risk factors and promote protective factors that foster school adaptation and educational inclusion of students, and prevent educational lag or even dropout. Moreover, it is essential to take into account that some factors identified as risk factors may be also included among the protective factors. One example is many students that were found to live with extended family, a situation that can be considered as a risk factor given that too many people are living in one house, which prevents them from studying, but also as a protective factor when, for instance, parents work far from their houses and spend 2 or 3 hours each day on public transportation in addition to 8 hours at work, and children stay at home in the care of grandparents, aunts and uncles, and cousins, especially if we take into account the conditions of social disadvantage and violence within the contexts in which many of them are living, as shown in Table 3.

\subsection{Intervention}

This phase consists of different intervention programs that are designed and implemented based on the risk/resilience profile results observed in every group. Based on the aforementioned categories, 26 programs have been

Table 2. Number of children who were eligible for diagnostic evaluation and special education categories into which they fall by school year and gender.

\begin{tabular}{|c|c|c|c|c|c|c|c|c|c|c|c|c|c|c|c|c|c|c|c|}
\hline $\begin{array}{c}\text { School } \\
\text { Year }\end{array}$ & $\mathrm{S}$ & & LIP & & & ID & & & BP & & & $\mathrm{W} / \mathrm{s}$ & & & LI & & & $\mathrm{G}$ & \\
\hline & & $\mathrm{m}$ & $\mathrm{f}$ & $\mathrm{T}$ & $\mathrm{m}$ & $\mathrm{f}$ & $\mathrm{T}$ & $\mathrm{m}$ & $\mathrm{f}$ & $\mathrm{T}$ & $\mathrm{m}$ & $\mathrm{f}$ & $\mathrm{T}$ & $\mathrm{m}$ & $\mathrm{f}$ & $\mathrm{T}$ & $\mathrm{m}$ & $\mathrm{f}$ & $\mathrm{T}$ \\
\hline 2006-07 & 1 & 6 & 7 & 13 & 1 & & 1 & 12 & 1 & 13 & 6 & 10 & 16 & 8 & 7 & 15 & 7 & 9 & 16 \\
\hline 2008-09 & 1 & 13 & 5 & 18 & & 2 & 2 & 4 & 0 & 4 & 11 & 7 & 18 & 3 & 1 & 4 & 3 & 9 & 12 \\
\hline \multirow{4}{*}{ 2010-11 } & 2 & 8 & 4 & 12 & 2 & & 2 & 15 & 5 & 20 & 5 & 7 & 12 & 7 & 3 & 10 & 12 & 10 & 22 \\
\hline & 3 & 10 & 6 & 16 & & & & & & & 7 & 5 & 12 & & & & 7 & 5 & 12 \\
\hline & 4 & & & 14 & & & 4 & & & 16 & 6 & 4 & 10 & & & & & & 5 \\
\hline & 2 & 2 & 2 & 4 & 1 & & 1 & 8 & 7 & 15 & 4 & 3 & 7 & 5 & & 5 & 4 & 11 & 15 \\
\hline \multirow[t]{2}{*}{$2012-13$} & 3 & 7 & 8 & 15 & & & & 11 & 9 & 20 & 9 & 8 & 17 & 3 & 2 & 5 & 2 & 1 & 3 \\
\hline & 4 & & & 9 & & & 2 & & & 3 & 6 & 4 & 10 & & & 1 & & & 22 \\
\hline \multirow{2}{*}{ 2014-15 } & 2 & 3 & 1 & 4 & 1 & & 1 & 3 & 3 & 6 & 2 & 3 & 5 & 3 & 2 & 5 & 6 & 4 & 10 \\
\hline & 3 & 6 & 7 & 13 & & & & 6 & 2 & 8 & 4 & 5 & 9 & 2 & 2 & 4 & 3 & 4 & 7 \\
\hline TOTAL & & 55 & 40 & 118 & 5 & 2 & 13 & 62 & 27 & 105 & 54 & 52 & 122 & 31 & 17 & 49 & 44 & 53 & 124 \\
\hline
\end{tabular}

Note: $\mathrm{S}=$ School; $\mathrm{m}=$ male; $\mathrm{f}=$ female; LIP = Low Intellectual Performance; ID = Intellectual Disability; $\mathrm{BP}=$ Behavior Problems; W/SLD = Written and Spoken Language Disorders; LI = Language Impairment; $\mathrm{G}=$ Giftedness.

${ }^{2}$ Not all instruments are administered to every child, only those relevant to the special education category into which the child possibly falls and that are likely to provide more information. 
Table 3. Common risk and protective factors at the individual, family, school, and social levels that are part of the risk/resilience profile characterization of the participant sample.

\begin{tabular}{|c|c|c|}
\hline & Risk & Protective \\
\hline 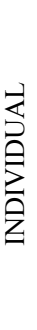 & $\begin{array}{l}\text { - Low intellectual levels. } \\
\text { - Disorders in the basic psychological processes: } \\
\text { attention, memory, thinking. } \\
\text { - Communication and language impairment. } \\
\text { - Low self-concept and self-esteem. } \\
\text { - Literacy learning disorders. } \\
\text { - Social relationship problems at school. } \\
\text { - Low cognitive and emotional self-regulation. } \\
\text { - Isolation and lack of confidence. }\end{array}$ & $\begin{array}{l}\text { - Average or high intellectual levels. } \\
\text { - Oral comprehension abilities. } \\
\text { - Appropriate spatial vision categorization and perceptual levels. } \\
\text { - Literacy learning at appropriate grade-levels. } \\
\text { - Pleasure in attending school. } \\
\text { - Joy and positive feelings. } \\
\text { - Feeling protected both at school and at home. } \\
\text { - Good physical and mental health level. } \\
\text { - Pleasure in playing with other children at school. } \\
\text { - Daily school attendance and integration in different activities. }\end{array}$ \\
\hline 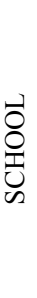 & $\begin{array}{l}\text { - Peer rejection. } \\
\text { - Low expectations of student achievement. } \\
\text { - Ineffective parent-teacher communication. } \\
\text { Inadequate identification of student's special } \\
\text { education needs. } \\
\text { - Failing. } \\
\text { - Isolation in the classroom. } \\
\text { Lack of teaching supports for special education } \\
\text { students. }\end{array}$ & $\begin{array}{l}\text { - Involvement in different support programs provided by the } \\
\text { secretariat of education. } \\
\text { - Teachers' concerns about student learning. } \\
\text { - Teacher collaboration with the Special Education Residency } \\
\text { program team. } \\
\text { - Continuous professional development of faculty. } \\
\text { - Leadership of principals from different schools and } \\
\text { open-mindedness in enabling the improvement of the school } \\
\text { process with varied proposals. }\end{array}$ \\
\hline 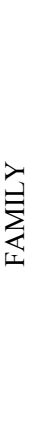 & $\begin{array}{l}\text { - Single-parenting family. } \\
\text { - Parent separation. } \\
\text { - Living with extended family. } \\
\text { - Lack of household rules. } \\
\text { - Alone until parents return from work. } \\
\text { - Domestic violence. } \\
\text { - Alcoholism. } \\
\text { - A parent is in prison. } \\
\text { - Lack of social support. } \\
\text { - Low income. } \\
\text { - Parents or primary careers are not involved in } \\
\text { - } \text { Lchool-related activities. }\end{array}$ & $\begin{array}{l}\text { - Parents love and care for their children. } \\
\text { - Some students are involved in extracurricular activities. } \\
\text { - Parents seek support to solve school and family problems. } \\
\text { - Family receives health care services. } \\
\text { - Satisfied fundamental needs. } \\
\text { - Able grandparents take care of their grandchildren if parents are } \\
\text { not at home or their workplace is distant from home. } \\
\text { - The extended family helps with the children. } \\
\text { - Acknowled have high academic expectations. } \\
\text { children's special needs. }\end{array}$ \\
\hline $\begin{array}{l}\underset{\Xi}{\Xi} \\
\underset{ٍ}{0}\end{array}$ & $\begin{array}{l}\text { - Living in socially disadvantaged environments. } \\
\text { - Violence and retail drug trafficking contexts. } \\
\text { - Not receiving health care services. } \\
\text { - Lack of leisure spaces. } \\
\text { - Lack of opportunities. }\end{array}$ & $\begin{array}{l}\text { - Laws aimed at reducing discrimination and promoting inclusion. } \\
\text { - Scholarships for students with disabilities. } \\
\text { - Actions to promote school harmony. } \\
\text { - Actions to reduce insecurity. }\end{array}$ \\
\hline
\end{tabular}

designed and implemented from 2006 to 2015 . Broadly, they are organized as follows.

1) Design, development, and implementation of specific programs, focused on students with special educational needs, and mainly on improving basic psychological processes including attention, memory, thinking, motivation and affection, self-esteem, self-concept, interpersonal relationships, and adaptive behaviors. A summative evaluation is conducted during implementation;

2) Design, development, and implementation of workshops for students' parents in intervention programs, focusing on aspects such as being familiar with the special educational needs of their children, knowing how to help them at home and how to improve the relationship with them, and expectations regarding their children, for example;

3) Design, development, and implementation of mentoring workshops for teachers on special education students, which provided special education training, including special education categories-particularly those that teachers may find in the classroom. In one school, for example, teachers asked for a workshop about social harmony in the school environment;

4) Assessment by portfolio is conducted with children and their parents, based on the portfolio they take home. The portfolio has been very useful, specifically for working parents who were not able to attend the workshops because of scheduling problems;

5) Activity log, where situations and events occurred during interventions are described. 
These programs are implemented during a complete school year. Table 4 shows that 305 students participated in them (i.e., $57.5 \%$ as many participants as in the diagnosis assessment phase and the $29.84 \%$ as many participants as in the screening phase), which $54 \%$ were boys and $46 \%$ girls. That reduction in the percentage is usually explained by two essential aspects: 1) teachers suspend participation in the program if, in their opinion, children have overcome difficulties and their presence in the classroom is preferred; and 2) parents relocate and, as a consequence, children change schools.

There were 286 parents who were able to attend the workshops, including $88 \%$ of female and $22 \%$ of male $\left(\mathrm{M}_{\mathrm{age}}=34(D E=6.6)\right.$ and $\mathrm{M}_{\mathrm{age}}=39(D E=6.9)$, respectively $)$. Attendance of a majority of women is explained by culturally-assigned female responsibilities of child care and education. Moreover, of the 29 attending teachers, 26 were female with an age range of 28 to 59 years $\left(\mathrm{M}_{\text {age }}=43.5\right)$ who had been teaching between 2 and 34 years. The teacher-student ratio was an average of $1 / 35$, with the number of students in a group varying from 30 to 40. In addition to the continuous communication with them during the school year, teachers attended a workshop on the characteristics of every special education category, in view of the fact that children with up to 6 identified special education categories may be found in every classroom.

\subsection{Final Assessment}

As mentioned above, in addition to the formative assessment conducted during the program implementation, a final assessment with the same tests administered during the initial assessment is conducted. Lastly, information related to the social validity of the program was obtained from both children and parents and teachers.

\subsubsection{Instruments}

- Social Validity Questionnaire for Intervention Programs in Special Education-Parents Version and Teachers Version (Cuestionario de validación social de programas de intervención en educación especial Versión Padres y Versión maestros) (Acle-Tomasini \& Ordaz Villegas, 2013), composed of 25 Likert-type items aimed at assessing the significance and acceptability of intervention programs in special education, regarding both evaluation and intervention procedures, using a 5-point scale: $1=$ Not at all; $2=$ Poorly; $3=$ Somewhat; $4=$ Very and $5=$ Extremely. It also included a blank space for parents to give feedback. Scale internal consistency, determined using Cronbach's alpha, is 0.956 . The internal consistency levels of dimensions were found to be 0.894 for acceptability, 0.894 for social relevance, and 0.884 for educational significance.

- Self-Evaluation Forms for students who participated in the programs.

Table 4. Number of children who participated in the intervention programs by special education category and gender.

\begin{tabular}{|c|c|c|c|c|c|c|c|c|c|c|c|c|c|c|c|c|c|c|c|}
\hline School Year & $\mathrm{S}$ & & IP & & & D & & & BP & & & //SL & & & LI & & & G & \\
\hline & & $\mathrm{m}$ & $\mathrm{f}$ & $\mathrm{T}$ & $\mathrm{m}$ & $\mathrm{f}$ & $\mathrm{T}$ & $\mathrm{m}$ & $\mathrm{f}$ & $\mathrm{T}$ & $\mathrm{m}$ & $f$ & $\mathrm{~T}$ & $\mathrm{~m}$ & $\mathrm{f}$ & $\mathrm{T}$ & $\mathrm{m}$ & $\mathrm{f}$ & $\mathrm{T}$ \\
\hline 2006-07 & 1 & 4 & 6 & 10 & 1 & 0 & 1 & 10 & 1 & 11 & 6 & 10 & 16 & 8 & 6 & 14 & 6 & 7 & 13 \\
\hline 2008-09 & 1 & & & & & & & & & & 5 & 2 & 7 & 2 & 1 & 3 & 3 & 9 & 12 \\
\hline \multirow{3}{*}{ 2010-11 } & 2 & 7 & 3 & 10 & 1 & & 1 & 7 & 1 & 8 & 4 & 2 & 6 & 4 & 1 & 5 & 8 & 11 & 19 \\
\hline & 3 & 5 & 2 & 7 & & & & & & & 6 & 5 & 11 & & & & & & \\
\hline & 4 & & & 6 & & & 1 & & & & & & & & & & & & \\
\hline \multirow{3}{*}{$2012-13$} & 2 & 2 & 2 & 4 & 1 & & 1 & 8 & 7 & 15 & 3 & 2 & 5 & 4 & & 4 & 4 & 11 & 15 \\
\hline & 3 & & & & & & & 9 & 4 & 13 & 4 & 6 & 10 & & & & & & \\
\hline & 4 & & & & & & & & & & 5 & 4 & 9 & & & & & & \\
\hline \multirow{2}{*}{ 2014-15 } & 2 & 3 & 1 & 4 & 1 & & 1 & 3 & 3 & 6 & 2 & 3 & 5 & 2 & 2 & 4 & 6 & 4 & 10 \\
\hline & 3 & 6 & 5 & 11 & 0 & 0 & 0 & 6 & 1 & 7 & 4 & 5 & 9 & 2 & 2 & 4 & 3 & 4 & 7 \\
\hline TOTAL & & 27 & 19 & 52 & 4 & 0 & 5 & 43 & 17 & 60 & 39 & 39 & 78 & 22 & 12 & 34 & 30 & 46 & 76 \\
\hline
\end{tabular}

Note: $\mathrm{m}=$ male; $\mathrm{f}=$ female; LIP = Low Intellectual Performance; ID = Intellectual Disability; $\mathrm{BP}=\mathrm{Behavior}$ Problems; W/SLD = Written or Spoken Language Disorders; LI = Language Impairment; $\mathrm{G}=$ Giftedness. S = School. 


\subsubsection{Results}

Regarding social validity, it was of important interest to know the general response of parents. Both parents and teachers who participated in the implementation during different school years used all five response options, but parents tended to the "Very" and "Extremely" options in most items. In this sense, as Barret, Shortt, Fox and Wescombe (2001) highlighted, social validity is described more as a process than as a statistical result, and the opinion of program participants acquires relevance in educational contexts when working in natural settings, because collected data has help to provide feedback to children, parents and teachers, but also has enriched the implementation of programs derived from the proposed model.

1) Intellectual Disability and Low-Intellectual Performance among students.

Overall, risk factors were found to decrease and protective ones to increase, both at the individual and school and family levels. At the individual level, García-Azua (2016), León (2011), Martínez-Cordero (2012), Martínez-Vargas (2016), and Meléndez (2008), after implementing their programs with children ages 7-9, whose intellectual levels ranged from 69 to 80 in the initial assessment, found significant changes in the total Intellectual Coefficient scores after program implementation. The intellectual level of some children was either normalized or increased by 15 points or more, a key factor related to how children were motivated. Moreover, all of them improved their working and short-term memory, perceptual organization, non-verbal thinking, and adaptive behavior skills. All these improvements positively affected their academic performance, since these improvements helped children to be promoted to the next grade. Simultaneously, the workshops for parents focused on understanding the relevance of play in their children's development, the characteristics that hindered academic learning, the strategies that parents can use at home in order to help, and how to express affection and talk to them, among others. Also, in addition to the continuous communication established from the very beginning, teachers were offered a workshop aimed at learning special education objectives and the characteristics of special education categories, particularly those that occur in the classroom. Upon program completion, both parents and teachers noted that adaptive behaviors related to health and safety in children, for example, had improved. They also noticed major progresses in children: they were more careful with homework, and social harmony improved among peers. Social validity comments on the program for children with ID and LIP were as illustrated below:

I could not say only five things that I liked about the program, because I loved every part of it, particularly the teacher. Thanks for everything. (A boy)

I noted major positive changes in my child's behavior, both in the way he learns and the way he perceives school work. The fact that he willingly attends sessions with the doctors is very positive. I can see he is happy about it. (A father)

I was pleased that you invited us to the sessions with students, specifically with students with LIP and behavior issues. (A teacher)

2) Students with Written and Spoken Language Disorders

Bernal (2009), Gómez (2011) and Martínez (2006) administered their programs to 6-8-year-old children who only presented with language disorders. Their main findings show significant outcomes in language articulation, auditory discrimination of sounds, comprehension of verbal instructions, and expression of ideas, opinions, and suggestions. When working in teams, children were able to express their points of view and come to an agreement, as well as telling a story in the appropriate order of events. In cases where, besides spoken language, there were issues with written language acquisition, Barrera (2016), Méndez (2010) and Reyes (2014) noted that once the program was completed, children's spoken language level was normalized Méndez (2010), Raggi (2016) and Reyes (2014) to an appropriate level of literacy according to their grade. Moreover, school learning motivation, self-esteem, self-regulation, and socialization were improved. The foundation for collaboration between faculty and administrative staff in schools, and parents was laid out. Portfolio assessment was found to be a wonderful technique which allows promoting resilient behaviors in children and their parents: children continued to use self-regulation and parents became more constantly involved in the formal education of their children. Social validity comments on the spoken and written language programs were as illustrated below:

It was fun; we learned to pronounce words properly, to write stories and letters. (A student)

I have a positive opinion of these programs; they help children get on well, express opinions and ideas, do chores and activities, so children enjoy them a lot. For my son, the program was really helpful. (A mother)

The pupil relationship is very important to ensure good results, respect, care and communication with parents. (A teacher) 
3) Students with Written Language Disorders

When working with 8-9-year-old students who have difficulties accessing literacy learning, López (2014), Martínez (2008), Meléndez (2014) Anaya (2012), and Romero-Medina (2014) noted that, first of all, students showed major changes towards the end of the program in reading, copy, dictation, spontaneous writing, and arithmetic activities, as well as their ability to express their ideas verbally. Their written work also improved dramatically. Secondly, major differences were found in the perception of parents regarding their children's learning before and after the program: it became evident that they noticed improvements in their children's reading, writing, and attention. Moreover, they noted that children were more interested in going to school, doing their homework and other tasks and school-related work; also, children were calmer, more obedient and showed a better disposition to complete activities. In fact, self-regulation was an essential aspect with regard to school learning, and also grades, as well as the relationship of children with their teachers and peers. Language issues were a major topic discussed in parents' and teachers' workshops, where students' needs and attention strategies and the difficulties that reading and writing learning can entail were identified. Social validity comments on the program for learning-impaired children were as illustrated below:

With the teachers' support, my children are giving me $90 \%$ at school and home. (A grandparent)

His pronunciation improved; he used to be quieter and now he's more talkative. He used to make mistakes when writing, but now, not so much. He does not feel stressed when he is doing his homework anymore, and the teacher told me that he has improved a great deal since he started working with you. (A mother)

Children can be referred or we can offer alternatives to improve writing, reading, self-confidence, safety, etc. (A teacher)

4) Students with Behavior Problems

On the one hand, Cid (2012), Domínguez (2008), Hernández (2016), Rodea (2016), Romero-Muñoz (2014), and Romero-Medina (2014) oriented their programs towards 6-8-year-old children with both externalized and internalized behavior problems. These authors focused the program activities on rule obedience, problem solving, self-regulation of emotions, self-esteem, self-confidence, and pro-social behaviors towards others. By the end of the intervention, significant changes were noted in aspects such as: rule and boundary identification both at school and in the household; description and suggestion of positive solutions to conflicts; improved ability to analyze problematic situations and respond appropriately; self-esteem improvement and improvement of relationships with peers, teachers, and parents. Parents' workshops were focused on topics such as: 1) discipline and boundaries in the household; 2) emotions and their role in educating children; 3) problem solving.

On the other hand, teachers were offered a workshop on the characteristics of behavior problems at school and relevant strategies they can apply in the classroom. Both parents and teachers noted positive changes in their relationship with children, because they established clear rules and respectful behavior became mandatory. Social validity comments on the program for children with behavior problems were as illustrated below:

The program helped to improve family-school relations. I wish the program was permanent, so the student's daily performance could be reinforced. Thank you; this professional work was focused on forming happy children that develop the necessary skills to successfully function in society, with the help of their parents, of course. (A father of a boy with externalized problems)

Her progress has been significant, both at school and in her socializing with people. (A mother of a girl with internalized problems)

It was essential to learn that the classroom should be governed by rules and to clarify the consequences of breaking those rules, as well as acknowledging the student's achievements. (A teacher)

5) Gifted Students

Romero (2008) and De Fuentes (2012) conducted enrichment-oriented programs through play, while Antonio (2014) and Durán (2016) focused on enrichment in the critical and creative thinking areas, to which Álvarez (2016) added a socioemotional focus. These programs were administered to 6-8-year-old children identified as gifted, whose individual, family, school, and community risk/resilience profile formed the basis for the design and implementation of the intervention program. The main findings of the post-testing phase show an increase in scores for Intelligence Quotient, Creativity Index and Critical Thinking Development, as well as significant changes in activities related to literacy and mathematic skills, and the emotional aspects regarding mostly self-concept and self-esteem. Workshops provided for parents and teachers focused mainly on understanding the characteristics of this children and lessening the stress under which they sometimes are. Also, parents and teachers acknowledge the importance of identifying and servicing this population. Social validity comments on 
the program for gifted children were as illustrated below:

I believe this program is very important as our children are provided with support. They are enjoying it. I see positive changes in my son, mostly regarding comprehension and analysis of things, the why, the purpose of things. (A father)

These programs provide support, and are very valuable because they help children socialize in harmony at school, at home and in their environment. (A mother)

You taught me to discuss instead of fighting, to know that I'm strong but I needn't fight. It was so much fun, and I enjoyed doing things with my hands and drawing. (A boy)

It was a really useful and enjoyable way to learn how to help children with these characteristics. It will help me with future planning and to improve personally. (A teacher)

\section{Discussion and Conclusions}

Educational resilience has the purpose of understanding why students in adverse environments succeed while others from equally adverse conditions do not. Authors like Fraser, Kirby and Smokowski (2004), Luthar (2007), Rutter (1993), and Ungar (2003) highlight the importance of doing resilience analysis from an ecological perspective, since recurring person-environment interactions are significant, and the active role of this correlation must not be overlooked. Resilience is not only associated to individuals' strength or weakness, but also to the way adverse stimuli affect or influence them and how they respond in the face of these conditions. Ungar also emphasizes that a wide range of personal and ecology factors correlated to the healthy functioning of children, youth and families in conditions of high risk has been successfully reported in the resilience literature. For Ungar, the problem underlies with how to explain the dynamic interaction between resilient factors and their sources.

In addition to the aforementioned, if unattended or unidentified, children with different special educational needs may face adversity, which can result in negative outcomes, such as educational lag or even dropout. The ecological risk/resilience model provides theoretical elements that allow for the understanding of special education children's interrelations at school. If possible, these elements help to offer intervention programs aimed at promoting the child's successful adjustment and educational inclusion, which in turn allows for theory-practice integration. Together with the importance of program involvement of special education children starting schooling, an emphasis is made on primary prevention; that is, early identification and intervention allow students to continue their studies in an adaptive manner.

Results obtained over 10 years of implementation of this ecological risk/resilience model in regular schools, where there are children who present with special educational needs, demonstrates that, as established by Poplin (1988): 1) the whole of the learned experience is greater than the sum of its parts; 2) the interaction of the learned experience transforms both the individual's whole and single experience. These aspects are essential to the experience of implementing the model; that is, if we analyze the process from initial assessment and intervention to final assessment, the whole obtained is much greater than its parts. Findings are relevant in determining evidence-based practice, as proposed by Cook et al. (2008), but it will be necessary to assess differences and similarities in other kinds of educational contexts, without overlooking the ecosystem and whole of every school.

In fact, in every school year, the model implementation has suffered some adaptations, which have been influenced by prior knowledge and own characteristics of people who develop and implement these intervention programs, bearing in mind the results obtained from previously implemented programs. Modifications have been made on the basis of the dynamic relationships that take place inside and outside school, so the need to conduct a transactional analysis, as suggested by Zipper and Simeonsson (2004) is emphasized. Moreover, in concordance with Murray (2003) and Wiener (2003) this study investigated the impact of programs on participants' individual, school, family and contextual experiences. At the same time, as highlighted by Donahue (2003), relevant data on the multiple, interactive characteristics of students starting schooling within their family, school, and social environments has been collected over time and from diverse populations.

From this ecological risk/resilience model framework (Acle-Tomasini, 2012), emphasis is made on the intertwined relationship between risk and protective factors among students facing educational risk or various adverse situations, such as being a member of a kidnapping family or having one parent in prison. This highlights the importance of programs with this perspective that are oriented towards promoting protective factors both at 
individual and the school and family level. This accounts for the results obtained by the implementation of different programs for children in all the special education categories. The mediator role of those who develop or implement the programs is particularly significant, since the mediation process addresses children's special educational needs, and parent and teacher expectations of student achievement, but at the same time mediators also mediate educational risk given that they must respond to two program-related fundamental questions: On which system must effort be focused to achieve adaptation of at-risk students? Which systems have the largest number of protective factors that help to mitigate risk?

The initial assessment shows a high incidence of children with special educational needs, an average of $54.5 \%$, which in turn falls into the categories of intellectual disability, low-intellectual performance, spoken language disorders, written and spoken language disorders, written language disorders, behavior problems and giftedness. Moreover, by characterizing a risk/resilience profile, common elements were found regardless of school year, school and types of problem, such as intra- and inter-individual risk factors among children; dysfunctional or single-parenting families; low levels of education, occupation, low income from parents; and parents in prison. At the educational level, some students from numerous groups of 30 to 40 members were found to present with special educational needs, and no official programs provide for identification and service for every children. Regarding the social environment, schools are located in socially-disadvantaged, violent, and drug abuse areas. Concurrently, protective factors, children willing to learn, teachers willing to teach and overcome problems in the classroom, and loving parents involved in improvement of child learning could be found. The school principals deserve a special mention for their leadership in allowing us to be involved and do our collaborative work.

This ecological risk/resilience model linking theory, practice, and research has sought rigorous planning and implementation of programs and measuring instruments, before, during and after. Statistically significant results regarding changes in psychological, educational, emotional, and social abilities that children showed upon completion of the program were obtained through quantitative methods. At the qualitative level, also significant changes were found in the parents-children, teachers-children, children-peers, and parents-teachers interactions after parents and teachers were provided with information to understand and guide action towards children. These changes are extensively documented through feedback about the social validity of the program, which also reinforces what Poplin (1988) stated: the whole is always greater than the sum of its parts.

\section{Limitations and Directions for Future Research}

Over the 10 years in which we have applied these programs based on the ecosystemic risk/resilience model, a major limitation lies in the fact that when we work in natural settings we are subject to administrative changes happening every year in schools, e.g. rotation of principals, teachers and students, which has made us to lose continuity in the implementation of the model, as well to search another settings. Considering that in studies carried out in Mexico, it has been reported that students with special education needs are more excluded than included inside the classroom (Consejo-Trejo, 2010; Peralta, 2009; Rubio \& Santoyo, 2004), and it will be relevant in the future to introduce specific programs for teachers through which we can provide them strategies to contend with those children with special education needs. So they will be able to promote then an inclusive education. On the other hand, the high rate of first graders students at risk with special education needs, leads us to take into account that in the future research it will be relevant to apply this model at the preschool level, in particular by the emphasis which is convenient to assign to the early childhood special education. To test this implementation of the ecosystemic risk/resilience model in special education, it will be important also: 1) to formalize the monitoring process with students, parents and teachers who have participated in the program that will allow us to assess the permanence of the resilient strategies and behaviors in the school learning process; and 2) to prove this model in different contexts to analyze the similarities and differences, as well as if in other contexts this application leads to students at risk to improve their learning and continue at school.

\section{Acknowledgements}

Projects granted by the Programa de Apoyo a Proyectos de Investigación e Innovación Tecnológica (PAPIIT, UNAM: IN300406, IN302812 y IN303615) [Support for Research and Innovation Projects Program, UNAM: IN300406; IN302812 and IN303615]. G.A.T. thanks to the Posgrade Students: Amanda Raggi R., Ana L. Meléndez A., Andrea Anaya P., Delma Cid C., Diana Romero M., Dully L. Domínguez M., Edith Romero G., 
Fabiana Romero M., Guadalupe Martínez G., Ileana Álvarez M., Irene Martínez V. Julieta Meléndez C., Katya Rodea R., Luna C. Bernal A.; Ma. de la Luz U., Ma. del Rosario Hernández G., María Teresa Martínez C., Melina Gómez G., Patricia de Fuentes Ch., Narcy Ma. León S., Rebeca Méndez A., Silvia Barrera M., Thamir D.D. Durán F., Yanet García A., Yessica Barrera S.

\section{References}

Acle, G., \& Roque, P. (2006). Guía de entrevista a padres [Parents Interview Guide]. In G. T. Acle (Ed.), Resiliencia en educación especial. Una experiencia en la escuela regular [Resilience in Special Education. An Experience in Elementary School] (pp. 97-103). España: GEDISA-UNAM-FES Zaragoza.

Acle-Tomasini, G. (2006). Educación especial. Investigación y práctica [Special Education: Research and Practice]. México: Plaza \& Valdés-UNAM.

Acle-Tomasini, G. (2012). Resiliencia en educación especial. Una experiencia en la escuela regular [Resilience in Special Education. An Experience in Elementary School]. España: GEDISA-UNAM-FES Zaragoza.

Acle-Tomasini, G., \& Ordaz-Villegas, G. (2013). Cuestionario de validación social de programas de intervenciónen educación especial: Versión padres y maestros [Social Validity Questionnaire on Special Education Intervention Programs for Parents and Teachers]. Unpublished Manuscript, México: Especial Education Residence, FES Zaragoza, Universidad Nacional Autónoma de México.

Álvarez, I., \& Romero, F. (2012). Prueba de Habilidades Matemáticas para Niños de Primer Ciclo [Test of Mathematics Skills for First Graders Children]. Unpublished Manuscript, Mexico: Special Education Residence, FES ZaragozaUNAM.

Álvarez, M. I. (2016). Uso del juego y del cuento para fomentar los factores protectores en niños con potencial sobresaliente: Validación social de un programa [Usage of the Game and the Story to Promote Protective Factors in Children with Outstanding Potential: Social Validity of a Program]. Unpublished Master's Thesis, Mexico: Universidad Nacional Autónoma de México.

Anaya, P. A. L. (2012). Problemas de aprendizaje y autorregulación en niños de primer ciclo: Una aproximaciónecológica [Learning Disabilities and Children Self Regulation in First Graders Children: An Ecological Approach]. Unpublished Master's Thesis, Mexico: Universidad Nacional Autónoma de México.

Antonio, C. A. (2014). Enriquecimiento cognitivo y creativo: Factor protector para los alumnos con aptitudessobresalientes en zonas marginadas [Cognitive and Creative Enrichment: Protective Factor for Gifted Students in Disadvantaged Areas]. Unpublished Master's Thesis, Mexico: Universidad Nacional Autónoma de México.

Barrera, M. S. (2016). Modelo ecosistémico de riesgo/resiliencia: validez social de un programa para niños conproblemas de lenguaje [Ecosystemic Risk/Resilience Model: Social Validity of a Program for Children with Language Problems]. Unpublished Master's Thesis, México: Universidad Nacional Autónoma de México.

Barret, P. M., Shortt, A. L., Fox, L. T., \& Wescombe, K. (2001). Examining the Social Validity of the Friends Treatment Program for Anxious Children. Behavior Change, 18, 63-77. http://dx.doi.org/10.1375/bech.18.2.63

Benard, B. (2004). Resiliency. What We Have Learned. San Francisco: West Ed.

Bernal, A. L. C. (2009). Programa de intervención con niños de primer ciclo con problemas de lenguaje. [Intervention Program for First Graders Children with Language Problems]. Unpublished Master's Thesis, México: Universidad Nacional Autónoma de México.

Bronfenbrenner, U. (1994). Ecological Models of Human Development. International Encyclopedia of Education, 3, 37-43.

Brown, H. J. (2004). Resilience. Emerging Social Constructions in Education Policy, Research and Practice. In H. C. Waxman, Y. N. Padrón, \& J. P. Gray (Eds.), Educational Resiliency. Student, Teacher and School Perspectives (pp. 11-36). Connecticut: Information Age Publishing.

Buck, J. N. Y. and Warren, W. L. (1994). Manual y guía de interpretación de la técnica de dibujo proyectivo H-T-P.[Manual and Guide for the Interpretation of de Projective Drawing Technique]. México: Manual Moderno.

Cid, C. D. (2012). Promoción de comportamientos resilientes en niños con problemas de conducta [Promotion of Resilient Behavior in Children with Behavioral Problems]. Unpublished Master's Thesis, México: Universidad Nacional Autónoma de México.

Consejo-Trejo, M. C. (2010). La integración educativa en preescolar-Xalapa. Estudio de caso [The Educational Integration in Preschool-Xalapa. A Case Study]. Unpublished Doctoral Dissertation's Thesis, México: Doctorado Interinstitucional de Educación de la Universidad Iberoamericana.

Cook, B. G., Tankersley, M., Cook, L., \& Landrum, T. J. (2008). Evidence-Based Practices in Special Education: Some Practical Considerations. Intervention in School and Clinic, 44, 69-75. http://dx.doi.org/10.1177/1053451208321452

Covarrubias, P. (2001). Lista para padres de familia y maestros regulares, para identificar el potencial sobresaliente en 
niños y niñas que cursan la educación primaria [Check List for Parents and Teachers to Identify Outstanding Potential in Children of Elementary Schools]. Unpublished Manuscript, México: Departamento de Educación Especial, Universidad Autónoma de Tlaxcala.

De Fuentes, Ch. M. P. (2012). Programa de enriquecimiento de la creatividad verbal y gráfica en niños sobresalientesde primer ciclo de primaria [Enrichment Program of Verbal and Graphical Creativity for First Gradersgifted Children]. Unpublished Master's Thesis, México: Universidad Nacional Autónoma de México.

Desatnik, O. (2009). Las relaciones escolares. Una visión sistémica [School Relations. A Systemic Vision]. México: Castellanos Editores.

Domínguez, M. D. L. (2008). Modelo de evaluación en intervención para niños con problemas de conducta [A Model of Evaluation and Intervention Program for Children with Behavioral Problems]. Unpublished Master's Thesis, México: Universidad Nacional Autónoma de México.

Donahue, M. L., \& Pearl, R. (2003) Studying Social Development and Learning Disabilities Is Not for the Faint-Hearted: Comments on the Risk/Resilience Framework. Learning Disabilities, Research \& Practice, 18, 90-93. http://dx.doi.org/10.1111/1540-5826.00064

Durán, F. Th. D. D. (2016). Validación social de un programa de enriquecimiento para alumnos sobresalientes bajo el modelo de riesgo/resiliencia [Social Validity of an Enrichment Program for Gifted Students Based on the Risk/Resilience Model]. Unpublished Master's Thesis, México: Universidad Nacional Autónoma de México.

Eggleston, J. (1977). The Ecology of School. London: Methuen.

Esquivel, F., Heredia, M. C., \& Lucio, E. (2007). Psicodiagnóstico clínico del niño [The Child Clinical Psychodiagnostic]. México: Manual Moderno.

Fraser, M. W. (2004).The Ecology of Childhood: A Multisystems Perspective. In M. Fraser (Ed.), Risk and Resilience in Childhood. An Ecological Perspective (pp. 1-12). Washington DC: National Association of Social Workers Press.

Fraser, M. W., \& Galinsky, J. M. (2004) Risk and Resilience in Childhood: Toward an Evidence-Based Model of Practice. In M. W. Fraser (Ed.), Risk and Resilience in Childhood. An Ecological Perspective (pp. 385-402). Washington DC: NASW Press.

Fraser, M. W., Kirby, D. L., \& Smokowski, P. R. (2004). Risk and Resilience in Childhood. In M. W. Fraser (Ed.), Risk and Resilience in Childhood. An Ecological Perspective (pp. 13-66). Washington DC: National Association of Social Workers Press.

García-Azua, Y. (2016). El juego para fortalecer conductas resilientes en niños con bajo rendimiento intelectualy discapacidad intelectual leve [The Play as a Tool for Strengthen Resilient Behavior in Children with Low Intellectual Performance and Intellectual Disabilities]. Unpublished Master's Thesis, México: Universidad Nacional Autónoma de México.

Gargiulo, R. M. (2010). Special Education in Contemporary Society: An Introduction to Exceptionality. Canada: Sage Publications.

Gómez, G. M. (2011). Modelo de evaluación e intervención en niños con problemas de lenguaje oral y escrito enlos primeros grados de primaria [An Assessment and Intervention Model for First Graders Children with Oral and Language Problems]. Unpublished Master's Thesis, México: Universidad Nacional Autónoma de México.

Hernández, G. M. del R. (2016). Validación social de un programa de intervención dirigido a estudiantes de primaria con problemas de conducta [Social Validity of an Intervention Program for First Graders Students with Behavioral Problems]. Unpublished Master's Thesis, Mexico: Universidad Nacional Autónoma de México.

Instituto Nacional de Estadística y Geografía (INEGI) (2010). Principales resultados del Censo de Población yVivienda 2010 [Main Findings of the Population and Dwelling 2010].

Kauffman, J. (1995). Why We Must Celebrate a Diversity of Restrictive Environments. The DLD Times, 12, 7-8.

León, S. N. M. (2011). Bajo rendimiento intelectual: evaluación e intervención [Low Intelectual Performance: Assessment and Intervention]. Unpublished Master's Thesis, México: Universidad Nacional Autónoma de México.

López, R. L. L. (2014). Promoción de la autorregulación: Factor protector para niños con problemas de aprendizaje [Fostering the Self-Regulation: Protective Factor for Children with Learning Disabilities]. Unpublished Master's Thesis, México: Universidad Nacional Autónoma de México.

Luthar, S. S. (2007). Resilience and Vulnerability: Adaptation in the Context of Childhood Adversities. New York: Cambridge University Press.

Margalit, M. (2003). Resilience Model among Individual with Learning Disabilities: Proximal and Distal Influences. Learning Disabilities, Research \& Practice, 18, 82-86. http://dx.doi.org/10.1111/1540-5826.00062

Martínez, B. L. M. (2006). Modelo de intervención para problemas de lenguaje oral y escrito en primer ciclo deprimaria [Intervention Model for Children with Oral and Writing Language]. Unpublished Master's Thesis, México: Universidad Nacional Autónoma de México. 
Martínez, B. L. M., Lozada, R. y Acle, G. (2013). Formato de percepción sobre lenguaje oral y escrito, socializacióny escuela [Schedule for Oral and Writing Language, Socialization and School]. Unpublished manuscript, México: Special Education Residence, FES Zaragoza-UNAM.

Martínez, G. G. (2008). Modelo de atención para niños de primer ciclo con dificultades de lectoescritura [An Intervention Model for First Graders Students with Learning Disabilities]. Unpublished Master's Thesis, México: Universidad Nacional Autónoma de México.

Martínez-Cordero, M.T. (2012). Detección e intervención temprana en niños con Bajo Rendimiento Intelectual. Un estudio de caso [Screening and Early Intervention in Children with a Low Intellectual Performance. A Case Study]. Unpublished Master's Thesis, México: Universidad Nacional Autónoma de México.

Martínez-Vargas, I. (2016). Validación social de un programa de intervención para consolidar la lectoescritura en estudiantes con bajo rendimiento intelectual [Social Validity of an Intervention Program to Strengthen Reading and Writing in Children with a Low Intellectual Performance]. Unpublished Master's Thesis, México: Universidad Nacional Autónoma de México.

Meléndez, A. A. L. (2014). Alumnos con problemas de aprendizaje en lectoescritura: intervención desde un modelo de enseñanza en autodeterminación [Studemts with Learning Disabilities: An Intervention Program Based on a SelfDetermination Teaching Model]. Unpublished Master's Thesis, México: Universidad Nacional Autónoma de México.

Meléndez, C. J. (2007). Inventario de conducta adaptativa para niños. Versión padres y profesores [Adaptative Behavior Children Inventory]. In G. Acle-Tomasini (Ed.), Resiliencia en educación especial. Una experiencia en la escuela regular [Resilience in Special Education. An Experience in Elementary School] (pp. 197-200). Mexico: GEDISA-UNAM-FEZ Zaragoza.

Meléndez, C. J. (2008) Programa para niños con discapacidad intelectual y bajo rendimiento académico en laescuela regular [Intervention Program for Children with Intelectual Disability and Low Intellectual Performance Attending Elementary School]. Unpublished Master's Thesis, México: Universidad Nacional Autónoma de México.

Méndez, A. R. (2010). Modelo de atención para estudiantes de primer ciclo de primaria con problemas del lenguajeoral y/o escrito [An Intervention Model for First Grader Studentes with Oral and/or Writing Disabilities]. Unpublished Master's Thesis, México: Universidad Nacional Autónoma de México.

Moreno, J. L. (1954). Fundamentos de la sociometría [Sociometry Foundations]. Buenos Aires: Paidós.

Murray, C. (2003). Risk Factors, Protective Factors, Vulnerability and Resilience. Remedial \& Special Education, $24,16-26$. http://dx.doi.org/10.1177/074193250302400102

Peralta, G. E. M. C. (2009). La integración educativa en la escuela regular desde la perspectiva de los docentes: Un acercamiento [The Educational Integration in the Regular School from the Perspective of Teachers. An Approach]. Unpublished Master's Thesis, México: Universidad Veracruzana.

Poplin, M. (1988). Holistic/Constructivist Principles of Teaching/Learning Process: Implications for the Field of Learning Disabilities. Journal of Learning Disabilities, 21, 401-416. http://dx.doi.org/10.1177/002221948802100703

Raggi, R. A. A. (2016). Atención a niños con problemas de lenguaje: Validación social de un programa en educaciónprimaria [Children with Langauage Problems: Social Validity of a Program at Elementary School]. Unpublished Master's Thesis, México: Universidad Nacional Autónoma de México.

Reyes, L. N. (2014). Factores de riesgo/resiliencia en niños con problemas de lenguaje oral y escrito [Risk/Resilience Factors in Children with Oral and Writing Disabilities]. Unpublished Master's Thesis, México: Universidad Nacional Autónoma de México.

Richman, J. M., Bowen, G. L., \& Woolley, M. E. (2004). School Failure: An Eco-Interactional Development Perspective. In M. W. Fraser (Ed.), Risk and Resilience in Childhood. An Ecological Perspective (pp. 133-160). Washington DC: NASW Press.

Rodea, R. K. R. (2016). Modelo de atención para niños con problemas de conducta: importancia de su validaciónsocial y educativa [Intervention Model for Children with Behavioral Problems: Relevance of Its Social and Educative Validity]. Unpublished Master's Thesis, México: Universidad Nacional Autónoma de México.

Romero, G. E. (2008). Modelo de atención para niños con aptitudes sobresalientes [Model of Service for Gifted Children]. Unpublished Master's Thesis, Mexico City: Universidad Nacional Autónoma de México.

Romero-Medina, F. (2014). Autorregulación: Estrategia para disminuir los factores de riesgo en estudiantes conproblemas de aprendizaje y conducta [Self-Regulation: Strategy for Decrease Risk Factors in Students with Learning Disabilities and Behavioral Problems]. Unpublished Master's Thesis, México: Universidad Nacional Autónoma de México.

Romero-Muñoz, D. E. (2014). Expresión literaria: Estrategia educativa para favorecer la autorregulación enalumnos con problemas de conducta [Literary Expresión: Educative Strategy to Promote Self-Regulation Instudents with Behavioral Problems]. Unpublished Master's Thesis, México: Universidad Nacional Autónoma de México.

Rubio, M. P., \& Santoyo, V. C. (2004). Interacciones sociales de niños con necesidades educativas especiales [Social 
Interactions of Children with Special Educational Needs]. Revista Mexicana de Análisis de la Conducta, 30, 1-20. http://dx.doi.org/10.5514/rmac.v30.i1.25201

Rutter, M. (1993). Resilience: Some Conceptual Considerations. Journal of Adolescent Health, 14, 626-631. http://dx.doi.org/10.1016/1054-139X(93)90196-V

Sánchez, E. P., Acle, T. G., De Agüero, S. M., Jacobo, M. A., \& Rivera, M. A. (2003). Educación Especial en México (1990-2001) [Special education at Mexico (1990-2001)]. En P. Sánchez (Coord.), Aprendizaje y Desarrollo [Learning and Development] (Vol. 4, pp. 189-374). México: Consejo Mexicano de Investigación Educativa.

Sattler, J. M. (2003). Evaluación infantil: Aplicaciones cognitivas. Volumen 1 [Child Assessment: Cognitive Applications. Volume 1]. Mexico: Manual Moderno

Secretaría de Educación Pública (SEP) (2000). Reflexiones de fin de siglo. Perspectivas del Siglo XXI [End of the Century's Reflections. XXI Century Perspectives]. México: SSEDF.

Stormont, M. (2007). Fostering Resilience in Young Children at Risk for Failure. Strategies for Grades K-3. Columbus, OH: Prentice Hall.

Torrance, E. P. (2008). Torrance Tests of Creative Thinking: Norms-Technical Manual: Figural. Benseville, IL: Scholastic Testing Service.

UNESCO (2003). Overcoming Exclusion through Approaches in Education. A Challenge and Vision. Conceptual Paper, Francia: UNESCO. http://unesdoc.unesco.org/images/0013/001347/134785e.pdf

Ungar, M. (2003). Methodological and Contextual Challenges Researching Childhood Resilience: An International Collaboration to Develop a Mixed Method Design to Investigate Health-Related Phenomena in At-Risk Child Population. http://www.resilienceproject.org/research/projects/international-resilience

Waxman, C. H., Padrón, N. Y., \& Gray, J. P. (2004). Educational Resiliency. Student, Teacher, and School Perspectives. Connecticut: IAP.

Wechsler, D. (2007). WISC-IV, Escala Wechsler de inteligencia para niños [Wechsler Intelligence Scale for Children] (4th ed.). México: Manual Moderno.

Weschler, D. (1981). WISC-R Español. Escala de Inteligencia Revisada para el nivel escolar [WISC-R Spanish. Weschler Intelligence Scale-Revised for school level]. México: Manual Moderno.

Wiener, J. (2003). Resilience and Multiple Risks: A Response to Bernice Wong. Learning Disabilities, Research \& Practice, 18, 77-81. http://dx.doi.org/10.1111/1540-5826.00061

Zipper, N. I., \& Simeonsson, J. R. (2004). Developmental Vulnerability in Young Children with Disabilities. In M. W. Fraser (Ed.), Risk and Resilience in Childhood. An Ecological Perspective (pp. 161-182). Washington DC: National Association of Social Workers Press. 